CZASOPISMO INŻYNIERII LĄDOWEJ, ŚRODOWISKA I ARCHITEKTURY JOURNAL OF CIVIL ENGINEERING, ENVIRONMENT AND ARCHITECTURE

JCEEA, t. XXXIII, z. 63 (4/16), październik-grudzień 2016, s. 329-337

Lech LICHOLAI ${ }^{1}$

Michał MUSIAE $^{2}$

\title{
WPEYW ORGANICZNYCH MATERIAŁÓW ZMIENNOFAZOWYCH NA EFEKTYWNOŚĆ ENERGETYCZNĄ PRZEGRODY PRZEZROCZYSTEJ
}

\begin{abstract}
W niniejszym artykule zaprezentowane zostały wyniki badań pokazujące wpływ zastosowania materiałów zmiennofazowych na poprawę efektywności energetycznej przegrody przezroczystej.

Autorzy przedstawili dotychczasowy stan wiedzy z zakresu materiałów zmiennofazowych oraz ich wykorzystania wraz z przeszkleniem lub elementami współpracującymi z nimi. Przytoczone zostały również niekonwencjonalne zastosowania materiałów zmiennofazowych, w których zasadne było wykorzystanie ciepła przemiany fazowej do poprawy funkcjonowania wybranych rozwiązań.

Badaniom zostało poddane przeszklenie o powierzchni $0,64 \mathrm{~m}^{2}$, w komorze o kubaturze $1 \mathrm{~m}^{3}$. Prace badawcze zostały przeprowadzone w rzeczywistych warunkach klimatycznych w Rzeszowie w III kwartale 2015 roku. Przeszklenie zostało poddane modyfikacji $\mathrm{z}$ wykorzystaniem paneli zawierających materiał zmiennofazowy, mobilnej izolacji termicznej magazynująco-refleksyjnej z zaaplikowanym materiałem zmiennofazowym oraz rolet $\mathrm{z}$ materiałem zmiennofazowym.

Otrzymane wyniki uzasadniają racjonalność użycia materiałów zmiennofazowych w celu zwiększenia bezwładności cieplnej przegrody, a co z tym związane zmniejszeniem wrażliwości wyżej wymienionej przegrody na chwilową zmianę temperatury powietrza zewnętrznego oraz natężenia promieniowania słonecznego.

Uzyskane wyniki ukazują zarówno potencjał powyższego zagadnienia, jak i jego wady. Kluczowe znaczenie ma odpowiedni dobór materiału zmiennofazowego (np. temperatura przemiany fazowej oraz ciepło topnienia-krzepnięcia).

Autorzy zwracają uwagę na funkcję, jaką ma spełniać opisywany materiał, poprzez jego ulokowanie w przegrodzie w zależności od potrzeby ograniczenia przechłodzenia oraz przegrzewania pomieszczeń. Niewłaściwy dobór wyżej wymienionych parametrów uniemożliwia efektywne wykorzystanie właściwości materiału zmiennofazowego.
\end{abstract}

Słowa kluczowe: substancje zmiennofazowe, przegrody przezroczyste, ciepło utajone, mobilna izolacja termiczna

\footnotetext{
${ }^{1}$ Autor do korespondencji / corresponding author: Lech Lichołai, Politechnika Rzeszowska, Zakład Budownictwa Ogólnego, ul. Poznańska 2, 35-959 Rzeszów; tel. 178651327; Lech.Licholai@ prz.edu.pl

${ }^{2}$ Michał Musiał, Politechnika Rzeszowska, Zakład Budownictwa Ogólnego, ul. Poznańska 2, 35-959 Rzeszów; tel. 178651005; mmusial@ prz.edu.pl
} 


\section{Wprowadzenie}

W celu zmniejszenia kosztów ogrzewania oraz chłodzenia pomieszczeń od lat prowadzone są badania z zakresu wykorzystania odnawialnych źródeł energii oraz efektywności magazynowania ciepła. Jednym ze sposobów na zwiększenie efektywności energetycznej przegrody budowlanej jest wykorzystanie materiałów zmiennofazowych PCM (ang. phase change materials).

Przykłady zastosowań wyżej wymienionych materiałów szerzej zostały opisane w [5] gdzie prezentowane są eksperymentalne wyniki badań oraz systematyzowany jest stan wiedzy w zakresie wykorzystania materiałów zmiennofazowych we współpracy z tradycyjnymi materiałami budowlanymi. Jako najczęściej spotykane PCMy w budownictwie wymienia się, opisane szerzej w [1], węglowodory nasycone, kwasy tłuszczowe i ich mieszanki oraz estry kwasów tłuszczowych. Przytoczone wyniki badań wskazywały, że stosowanie materiałów zmiennofazowych w przegrodach budowlanych powoduje zmniejszenie dobowych wahań temperatury powietrza $\mathrm{w}$ pomieszczeniach, powoduje obniżenie zużycia energii potrzebnej do ogrzewania oraz klimatyzowania budynków o lekkiej, szkieletowej konstrukcji oraz wydłuża czas, w którym temperatura powietrza wewnątrz budynku jest w zakresie komfortu cieplnego.

Badacze w [5] odnoszą się do wielu przykładów zastosowań PCMów w budynkach, zarówno w przegrodach przezroczystych jak i nieprzezroczystych. Wart wspomnienia jest przykład elementów ściennych, zbudowanych z wymiennika ciepła w postaci miedzianego orurowania wraz z dodatkowymi rurkami z PCMem jako magazynem ciepła. Powyższe elementu zostały umieszczone w ścianach polowych komór badawczych, a otrzymane wyniki wskazały na obniżenia wartości gęstości strumienia ciepła w sezonie letnim o odpowiednio $11 \%, 21 \%$, w przypadku zastosowania granulatu PCM w stosunku wagowym $10 \%$ i $20 \%$ całej przegrody.

Kolejnym opisanym przykładem użycia materiałów zmiennofazowych jest ich zastosowanie $\mathrm{w}$ systemach wykorzystujących pośrednie zyski z promieniowania słonecznego. Opisane w [2],[3],[4] wyniki badań wskazują na możliwe zwiększenie wydajności ścian kolektorowo akumulacyjnych. Poprawa efektywności spowodowana jest zwiększeniem akumulacyjności termicznej w związku z wysoką wartością ciepła utajonego PCMów.

W pracach [7],[8],[9] przedstawione zostały efekty nasycania porowatych materiałów ceramicznych substancjami zmiennofazowymi w celu poprawy ich przewodności cieplnej poprzez wypełnienie porów pianki grafitowej, względem samej parafiny. Z kolei wzrost przewodności cieplnej materiałów ceramicznych nasyconych PCMem skutkuje zwiększeniem efektywności cieplnej PCMu w przegrodzie budowlanej.

Kolejnym przykładem wykorzystania PCM w budownictwie jest opisane w [6] system wykorzystujący materiał zmiennofazowy w celu poprawy efektywności energetycznej przegrody przezroczystej. Zaprezentowane wyniki wskazują na możliwość wydłużenia czasu, w ciągu doby, w jakim temperatura 
powietrza w pomieszczeniach znajduje się w pożądanym zakresie, w porównaniu z tradycyjnym przeszkleniem.

\section{Cel prowadzonych badań}

Celem niniejszych badań jest określenie wpływu zastosowania mobilnej izolacji termicznej zawierającej materiał zmiennofazowy na zmniejszenie szczytowych wartości temperatury $\mathrm{w}$ pomieszczeniu $\mathrm{w}$ sezonie grzewczym $\mathrm{w}$ rzeczywistych warunkach klimatycznych. Artykuł stanowi kontynuację badań prowadzonych nad poprawą efektywności energetycznej przegród przezroczystych oraz elementów współpracujących z nimi, poprzez wykorzystanie w ich budowie substancji zmiennofazowej [1]. Elementem współpracującym z przeszkleniem, który został poddany badaniom oraz został opisany w niniejszej pracy, jest mobilna izolacja termiczna w formie rolety zamontowanej po wewnętrznej stronie przeszklenia.

\section{Budowa stanowiska badawczego oraz aparatury pomiarowej}

Niniejsze stanowisko badawcze stanowi sześcienna komora o kubaturze $1 \mathrm{~m}^{3}$ zbudowana z pięciu ścian z polistyrenu ekstrudowanego o grubości $10 \mathrm{~cm}$ oraz okna dwukomorowego z stolarką aluminiową. Pomiary zostały wykonane w rzeczywistych warunkach klimatu zewnętrznego w Rzeszowie, jesienią 2015 roku.

Wnętrze komory zostało podzielone w pionie na dwie części o jednakowej objętości, a przepierzenie zostało wykonane z polistyrenu ekstrudowanego o grubości $5 \mathrm{~cm}$. Po obu stronach przepierzenia zamontowana została roleta wewnętrzna, której zewnętrzna strona została pokryta czarną, matową farbą (rys.3, rys.4, rys.5, rys.6). $\mathrm{W}$ jednej $\mathrm{z}$ rolet umieszczony został mikrogranulat zawierający materiał zmiennofazowy Micronal ${ }^{\circledR}$, wyprodukowany przez firmę BASF (rys.1, rys.2).

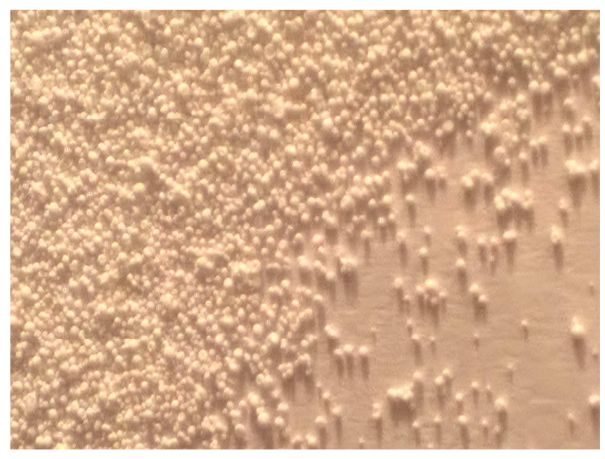

Rys.1. Powlekane mikrokapsułki zawierające materiał zmiennofazowy, (nazwa handlowa Micronal®)

Fig.1. Coated microcapsules containing PCM

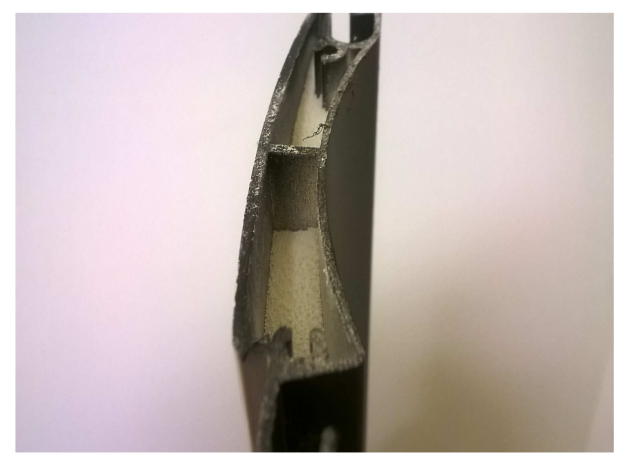

Rys.2. Przekrój porzeczny przez element mobilnej izolacji termicznej zawierający Mikronal®

Fig.2. Cross section of reflective-buffering movable thermal insulation 
Do komory badawczej zamontowane zostały czujniki natężenia promieniowania słonecznego oraz temperatury wewnątrz oraz na zewnątrz komory. Czujniki temperatury wewnątrz komory umieszczono po każdej stronie przepierzenia, w przestrzeni między szybą a roletą, po wewnętrznej stronie rolety oraz za roletą, pośrodku każdej połowy komory.

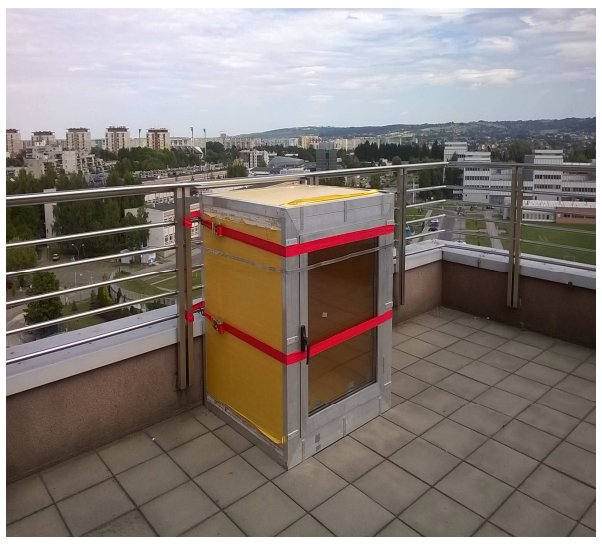

Rys.3. Widok komory badawczej znajdującej się na tarasie budynku P. Politechniki Rzeszowskiej

Fig.3. Research chamber on a terrace of building P, University of technology in Rzeszów

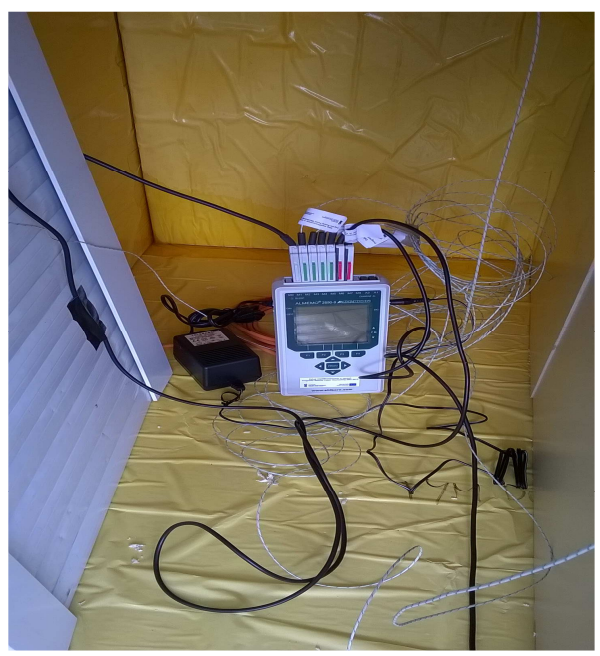

Rys.5. Zdjęcie aparatury pomiarowej wraz z rejestratorem

Fig.5. Measuring instruments with data logger

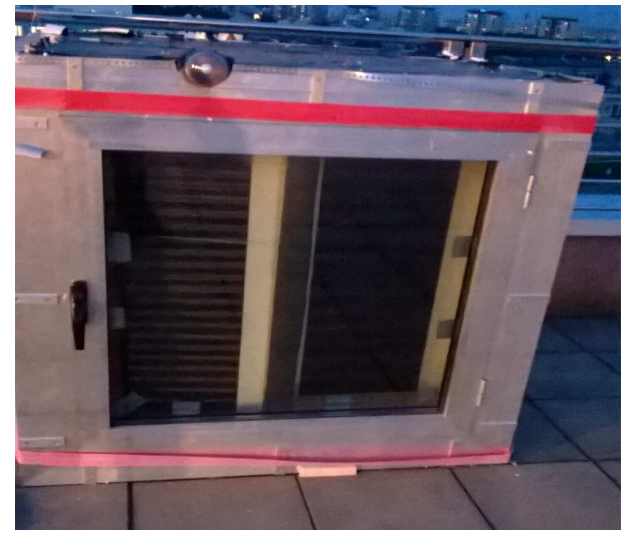

Rys.4. Widok komory badawczej z zamontowaną mobilną izolacją termiczną

Fig.4. Research chamber with installed reflectivebuffering movable thermal insulation

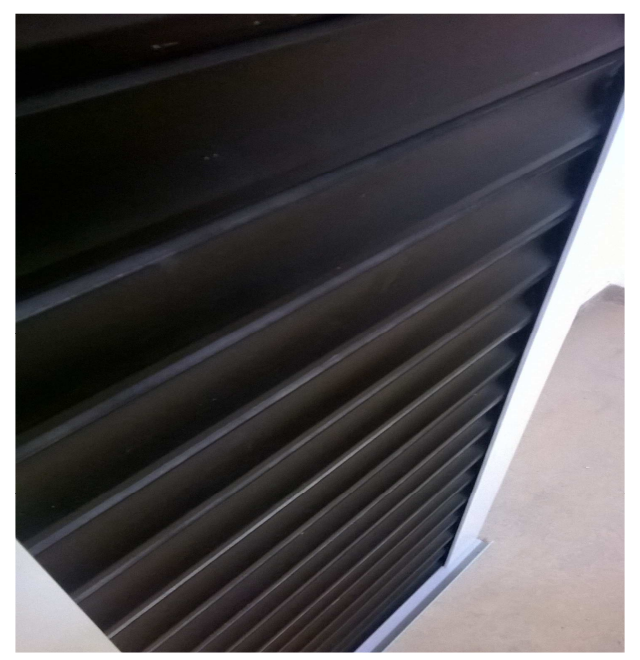

Rys.6. Zdjęcie prototypu mobilnej izolacji termicznej z PCMem od strony powłoki absorpcyjnej

Fig.6. Prototype of reflective-buffering movable thermal insulation. Picture taken from absorption coating side 
Dokładny schemat budowy stanowiska badawczego oraz miejsce zamontowania czujników pomiarowych został zamieszczony poniżej na (rys.7).

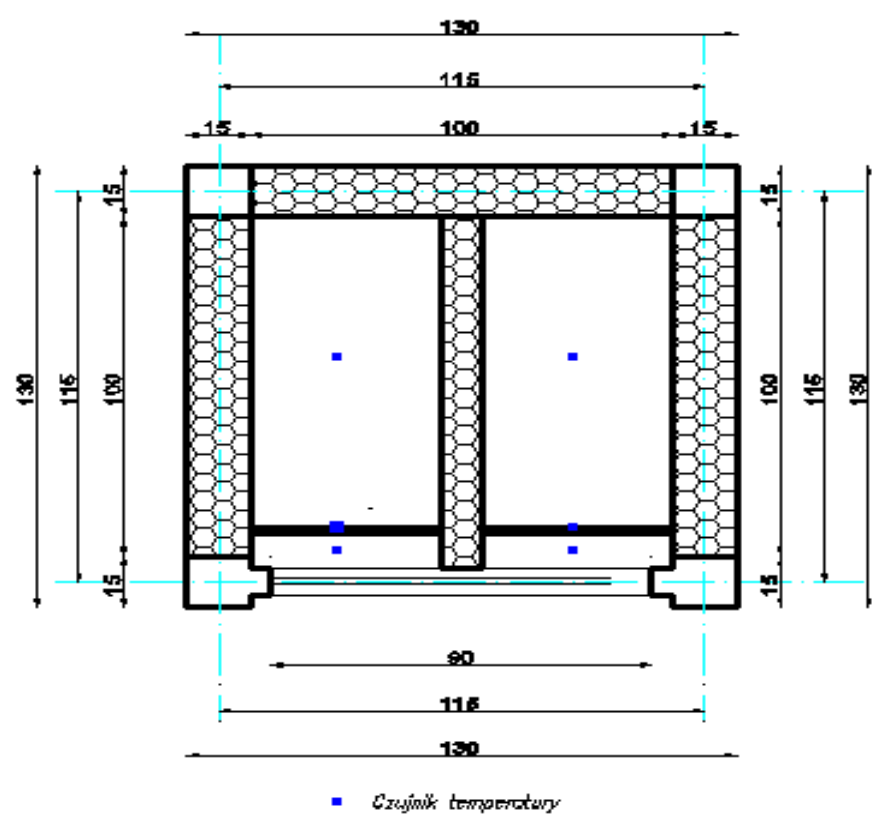

Rys.7. Przekrój poprzeczny przez komorę badawczą

Fig.7. Research chamber cross section

Wszelkie wyniki pomiarowe zostały odczytane oraz zachowane przez rejestrator Ahlborn (rys.5.) w odstępach co 10 min.

\section{Wyniki}

Komora badawcza znajdowała sie na tarasie Budynku Politechniki Rzeszowskiej, a pomiary wykonywane były w okresach wysokiego natężenia promieniowania słonecznego.

Poniżej przedstawione zostały wykresy natężenia promieniowania słonecznego oraz temperatury powietrza, które występowały w czasie rejestrowania pomiarów (rys.8, rys.9). 


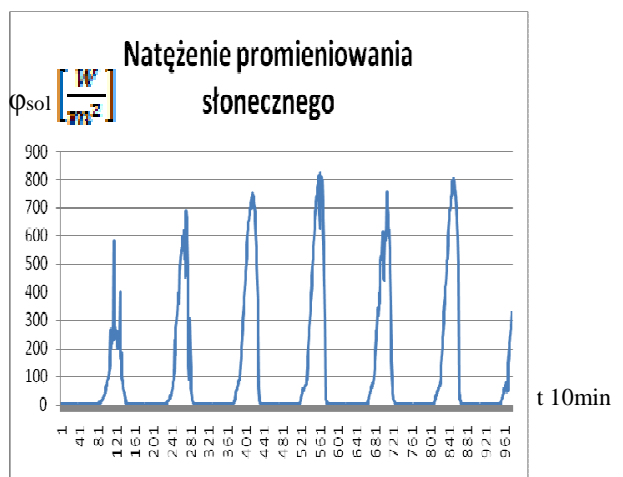

Rys.8. Natężenie promieniowania słonecznego podczas prowadzenia pomiarów

Fig.8. Solar irradiance during the research

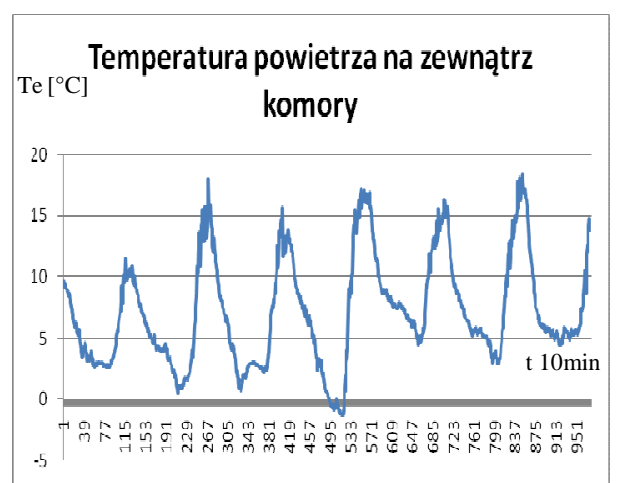

Rys.9. Temperatura powierza na zewnątrz komory Fig.9. External air temperature

Przedstawione poniżej wyniki temperatur (rys.10, rys.11) na powierzchniach samego przeszklenia oraz przeszklenia $\mathrm{z}$ mobilną izolacją termiczną zawierającą materiał zmiennofazowy, ukazują znaczne obniżenie szczytowych wartości temperatur zarówno powierzchni przeszklenia i rolet, jak i temperatury powietrza wewnątrz komory.

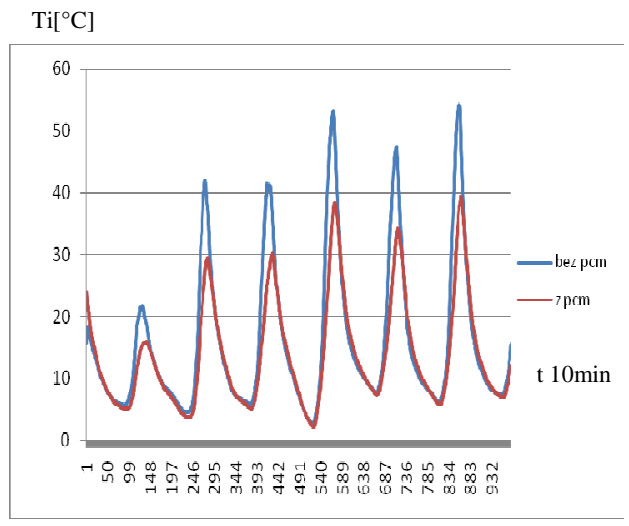

Rys.10. Temperatura wewnątrz komory za roletą i przeszkleniem

Fig.10. Air temperature inside the chamber

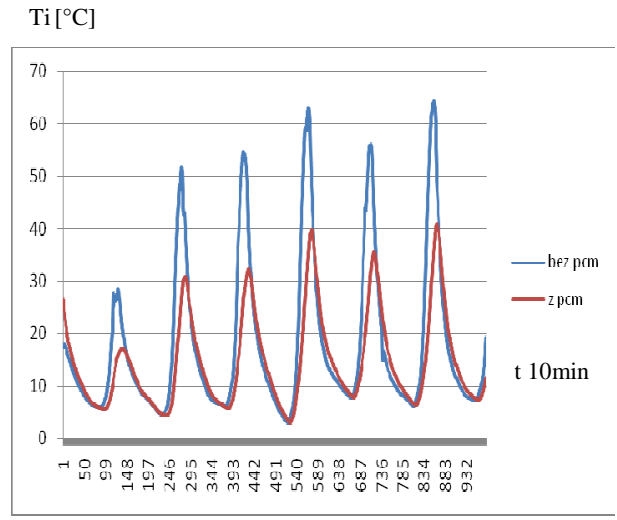

Rys.11. Temperatura na powierzchni przeszklenia i żaluzji

Fig.11. Temperature on IGU's and shutters' surfaces

Otrzymane wyniki potwierdzają zakładane właściwości materiałów zmiennofazowych, które skutkują ograniczeniem przegrzewania komory w momencie występowania wysokich wartości natężenia promieniowania słonecznego, a w momencie jego obniżenia, zaobserwowano dogrzewanie wnętrza komory po 
stronie z PCMem. Dogrzewanie związane jest z uwolnieniem energii utajonej PCMu w skutek jego krzepnięcia. Nieco mniejsza od zakładanej efektywność powyższego rozwiązania, spowodowana jest zbyt wysoką temperaturą przemiany fazowej PCMu $34-36{ }^{\circ} \mathrm{C}$, stosunkowo niedużą wartością ciepła przemiany fazowej ok $115 \mathrm{~J} / \mathrm{g}$ oraz trudnościami w przekazywaniu ciepła wewnątrz rolet, spowodowanymi postacią PCMu - mikrogranulat.

Wartość entalpii przemiany fazowej mikro kapsułek Micronal@ podczas ogrzewania oraz chłodzenia próbki została określona za pomocą skaningowego mikrokalorymetru różnicowego DSC (rys.12).

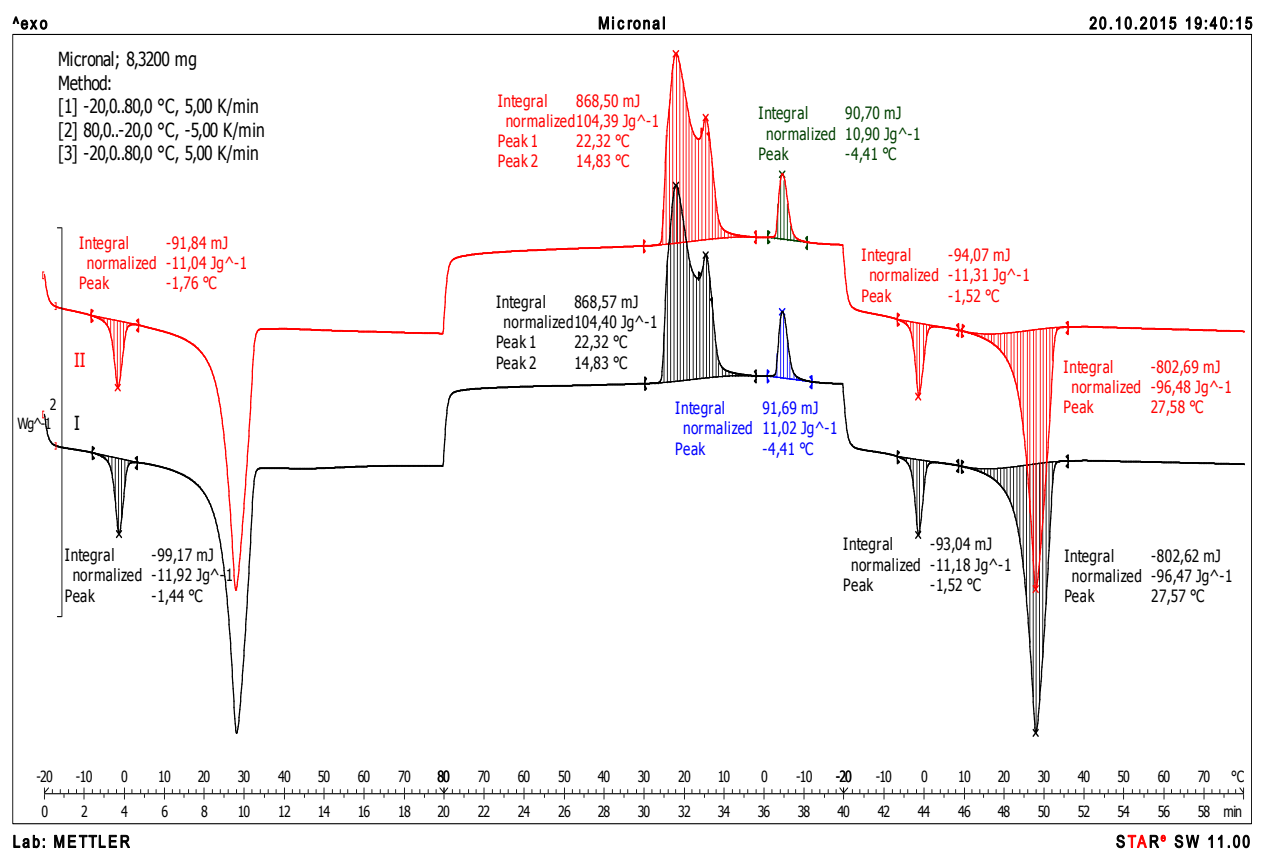

Rys.12. Wykres kalorymetryczny mikro kapsułek Micronal® zawierających organiczną substancję zmiennofazową

Fig.12. Enthalpy in function of temperature. Characteristic of Micronal® microcapsules with organic PCM

Na powyższym wykresie zaobserwować można podział entalpii topnienia oraz krzepnięcia na dwa obszary przy różnych temperaturach. Powyższe zjawisko wpływa negatywnie na sprawność całego rozwiązania, ponieważ część ciepła utajonego $\mathrm{w}$ materiale zmiennofazowym zostanie oddana do otoczenia dopiero przy temperaturach rzędu (ok. $\left.-5^{\circ} \mathrm{C}\right)$. 


\section{Wnioski}

Przedstawione w niniejszej pracy wyniki badań jednoznacznie wskazują na obniżenie szczytowych wartości temperatury przeszklenia z zastosowaną roletą z PCM, względem komory z roletą kontrolną. Wyniki otrzymane w rzeczywistych warunkach klimatu zewnętrznego przedstawiają mniejszą od zakładanej stabilizację temperatury wewnątrz komory poprzez dobór niewłaściwego materiału zmiennofazowego.

Na podstawie wyników kalorymetrycznych określono rzeczywistą wartość entalpii przemiany fazowej ok $115 \mathrm{~J} / \mathrm{g}$. Zaobserwowano różne zakresy ciepeł przemiany fazowej podczas topnienia oraz krzepnięcia, przy różnych zakresach temperatur np. $\Delta \mathrm{H}_{\mathrm{krzl}}=105,39[\mathrm{~J} / \mathrm{g}] \mathrm{dla} \Delta \mathrm{T}_{\mathrm{krzl}}=\left(\operatorname{od} 30^{\circ} \mathrm{C}\right.$ do $\left.15^{\circ} \mathrm{C}\right)$ oraz $\Delta \mathrm{H}_{\mathrm{krz} 2}=10,90[\mathrm{~J} / \mathrm{g}] \mathrm{dla}$ $\Delta \mathrm{T}_{\mathrm{krz} 2}=\left(\right.$ od $5^{\circ} \mathrm{C}$ do $\left.-10^{\circ} \mathrm{C}\right)$.

Mankamentem badanego materiału zmiennofazowego, poza stosunkowo niską wartością ciepła przemiany topnienie-krzepnięcie (ok.115 J/g), jest istnienie przestrzeni powietrznych między poszczególnymi granulkami PCM, co zmniejsza sprawność przekazu ciepła wewnątrz listew rolet.

Na podstawie przeprowadzonego przeglądu stanu wiedzy z zakresu wykorzystania PCM w budownictwie oraz wykonanych badań autor zauważa potrzebę doboru takiej substancji PCM, aby temperatura przemiany fazowej była zbliżona do maksymalnych osiąganych w miejscu jej aplikacji.

Pomimo dużego zainteresowania badaczy powyższym zagadnieniem na rynku materiałów budowlanych w dalszym ciągu brak gotowych, ogólnodostępnych produktów. $\mathrm{Z}$ tego względu niezbędne są dalsze badania, mające na celu poprawę wydajności wyżej wymienionych rozwiązań oraz poprawę właściwości samych substancji zmiennofazowych.

\section{Literatura}

[1] Musiał M.: Zastosowania materiałów zmiennofazowych (PCM) w budownictwie, s. 42-45, 2015. Dom Wydawniczy Medium, Izolacje z. 195.

[2] Krasoń J., Lichołai L.: Określenie wpływu impulsów termicznych na wewnętrzne zmiany temperaturowe $\mathrm{w}$ elementach silikatowych zmodyfikowanych materiałem zmiennofazowym, Czasopismo Inżynierii Lądowej, Środowiska i Architektury Journal of Civil Engineering, Environment and Architecture, JCEEA, t. XXXI, z. 61 (3/II/14), 2014, s. 307-316, DOI:10.7862/rb.2014.97.

[3] Krasoń J.: Możliwości zastosowania materiałów zmiennofazowych w pasywnych rozwiązaniach ściennych elementów murowych, Czasopismo Inżynierii Lądowej, Środowiska i Architektury - Journal of Civil Engineering, Environment and Architecture, JCEEA, t. XXXI, z. 61 (3/II/14), 2014, s. 297-306, DOI:10.7862/rb.2014.96.

[4] Krasoń J., Lichołai L.: Badania laboratoryjne cieplnego funkcjonowania przegród kolektorowo-akumulacyjnych modyfikowanych materiałem zmienno-fazowym, Fizyka budowli w teorii i praktyce. tom VII, nr 2, 2015, str. 39-44. 
[5] Goia F., Perino M., Serra V.: Improving thermal comfort conditions by means of PCM glazing systems Energy Build, 60 (2013), pp. 442-452.

[6] Kenisarin M., Mahkamov K.: Passive thermal control in residential buildings using phase change materials, Renewable and Sustainable Energy Reviews Volume 55, March 2016, pp. 371-398.

[7] Xiangfa Z., Hanning X., Feng J., Changrui Z., Yonggang J.: Preparation and thermal properties of paraffin/porous silica ceramic composite, Composites Science and Technology 69 (2009), pp. 1246-1249.

[8] Xiangfa Z., Hanning X., Feng J., Changrui Z., Yonggang J.: Pore structure modification of silica matrix infiltrated with paraffin as phase change material, Chemical Engineering Research and Design 88 (2010), pp. 1013-1017.

[9] Yajuan Z., Quangui G., Sizhong L., Jingli S., Lang L.: Heat transfer enhancement of paraffin wax using graphite foam for thermal energy storage, Solar Energy Materials \& Solar Cells 94 (2010) pp. 1011-1014.

\section{INFLUENCE OF AN ORGANIC PHASE CHANGE MATERIALS ON ENERGY EFFICIENCY OF TRANSPARENT BARRIER}

\section{S u m m a r y}

This paper describes the results of the research that presents an improving influence of organic PCM on energy efficiency of transparent barrier. Author reviewed an actual knowledge concerning phase change materials and their applications with insulated glass units and other elements of transparent barriers.

Unconventional applications of phase change materials in civil engineering were also mentioned. Insulated glass unit of $0,64 \mathrm{~m}^{2}$ surface area was studied in research chamber of one cubic meter volume. Research were conducted in Rzeszów, under real world, outdoor conditions, during third quarter of 2015 year. Insulated glass unit was equipped interchangeably using PCM containing panels, shutters filled with phase change material and with so called reflective-buffering movable thermal insulation.

The results obtained justify using phase change materials as a mean of increasing thermal inertia of the barrier, therefore making it less susceptible for external temperature and solar irradiance changes. Proper choice of phase change materials and its properties, especially melting point and latent heat of fusion) appears to be essential if proper improvement is to be achieved.

Author emphasizes the necessity to predetermine the function of the modification (overheating or overcooling protection), as the function strongly influences an optimal location of phase change material. Improper choice of properties or location of phase change material makes impossible to take full advantage of its potential.

Keywords: Phase change materials, transparent barriers, latent heat, movable thermal insulation

DOI: $10.7862 / \mathrm{rb} .2016 .277$

Przestano do redakcji: $30.06 .2016 r$.

Przyjęto do druku: 20.12.2016 r. 
